20,000 participants. Besides teachers in secondary schools and colleges attending 348 'courses' varying in length from 4 to 12 weeks, 515 teachers and supervisors in elementary schools received training in 12 summer schools ; technical school personnel were provided for in two experimental summer programmes and 546 college teachers of science and mathematics attended 20 summer conferences dealing with special fields of science and mathematics. Under the Academic Year Institute programme, providing a year's study in science and mathematics for secondary school teachers, awards were made to 32 colleges and universities, and it is estimated that the 1959-60 programme will support more than 1,500 teachers ; while opportunities for further study in out-of-school hours will be provided to about 9,000 secondary school teachers under the In-Service Institutes programme. Special projects in science education on which nearly 9 million dollars was expended cover visits of scientists to secondary schools, the provision of a travelling science library of carefully selected books for high schools, a travelling science demonstration lecture programme for secondary schools and support for summer training of secondary school students. The State Academies of Science, the College Programme and Teacher Improvement Programmes provide for visits by scientists, and foster the participation of undergraduates in research, supplementary training for science teachers and eight special field institutes covering advanced training in highly specialized subjects. On the Course Content Improvement Programme, a further 6 million dollars was expended on projects in elementary and secondary schools and in colleges ; this included supplementary teaching aids such as films and television. Activities under the International Science Education Programme initiated during the year include the improvement of science curricula and the training of teachers and also measures to assist science students and scientists to engage in international educational programmes.

The Scientific Man-Power Programme, on which 780,000 dollars was expended in 1959 , besides maintaining the National Register of Scientific and Technical Personnel, initiated surveys of scientific and technical employment in private industry and State Governments, of seientific and technical personnel in colleges and universities, and of scientists and engineers in Federal Government employment engaged in research, and pilot studies of the demand for scientists and engineers in several industries. Reports were completed on the knowledge of foreign languages of American scientists in 1954-55, on scientists and engineers in American industry in January 1957, and on employ- ment and other charactoristics of American scientific man-power during 1954-55. The measurement and appraisal of the national research and development effort is a major responsibility of the Foundation, and its Office of Special Studies has now completed its surveys of the year 1953-54; its present programme of statistical surveys proposes a detailed survey of each sector every four or five years, summary data only being collected in the intervening years. During the year, a survey was made of expenditure on scient. ific resэarch and developm 1959 and 1960 , and a survey of szientific research and development expenditure and man-power in colleges and universities during $1957-58$ is now being conducted, following the publication of the report on the 1953-54 survey.

During the year, further responsibilities for improving the availability of research information to scientists were assigned to the Foundation by the National Dofense Education Act, 1958, and accordingly the Office of Science Information Service and the Federal Advisory Committee on Scientific Information have boen established. For the dissemination of ssientific information, 146 grants totalling 3.8 million dollars were made for such purposes as documentation research, the international exchange of scientific information, the support of scientific publications and information services and the dissemination of unpublished research information such as unpublished Government research reports. Studies of the flow of information among scientists and of the scientific activity of chemists were completed during the year and five mechanical translation projects are at present supported, as well as the effort of 28 professional societies and academic institutions in providing translations of 35 Russian scientific and technical periodicals and 18 books and monographs. A Foreign Technical Information Centre has been established in the Office of Technical Services of the Department of Commerce, where scientific and technical translations prepared by Government agencies are collected, and their availability is announced. Support of scientific publications covered the issue of Physical Review Letters, an experiment in rapid low-cost publication of short, up-to-the-minute articles on physical research, support for the Journal of Geophysical Research and a grant to enable Biological Abstracts to extend its coverage; while grants in support of information services include one to the Bio-Sciences Information Exchange, administered by the Smithsonian Institution, and continued support to the Office of Critical Tables of the U.S. National Academy of Sciences.

\title{
THE PUBLIC AND THE BROADCASTING PROGRAMMES IN BRITAIN
}

$\mathrm{T}$

THE British Broadcasting Corporation has issued a report on an inquiry carried out at the end of 1958 by its Audience Research Department*. Its first chapter describes the public and the facilities which are available for listening and viewing, com-

* British Broadcasting Corporation. The Public and the Programmes: an Audience Research Report on Listeners and Viewers, the time they devote to listening and viewing, the Services they British Broadcasting Corporation, 1959.) $8 \delta .6 \dot{d}$. paring the public which depends solely on sound broadeasting with that which has television as well, and also contrasting viewers who can receive B.B.C. television only, with those who can also receive Independent television. The following three chapters deal successively with listening in the evening, viewing in the evening and listening in the day-time, contrasting the amount of listening or viewing, the selectiveness of listeners or viewers and the dis- 
tribution of their patronage. A fifth chapter discusses the tastes of listeners and viewers as they emerge when people have a chance to express their views in respect of a range of categories of programme output, and includes a comparison of the tastes of men and women of different age groups and different educational levels. Each chapter ends with a summary of its main findings, but a concluding section of the report entitled "Highlights and Reflections" attempts to view the results as a whole. At the present time there are three distinct publics. The first, 'Band 1/3', which can receive both B.B.C. and Independent television and also sound broadcasting (now about half the population), is gradually swallowing up the other two: 'Band 1', which ean receive B.B.C. television and sound (now about 20 per cent), and the 'sound only', which cannot receive television (now about 30 per cent). About 15 per cent had very high frequency receivers, and three-quarters of these are in television homes. The 'sound only' public is somewhat older and of a slightly higher educational level than the 'sound and television' public, and on average families in this group are a good deal smaller than 'sound and television' families. The 'Band l' public also was somewhat older and of a rather higher educational standard than the 'Band $1 / 3$ ' public.

The typical viewer watches television in winter for approaching two hours each evening, and this means that at peak hours not far short of half the adult population is watching television. The typical listener has his radio on for not much more than half an hour a night and will usually be doing something else at the same time. In television homes sound broadcasting is used very little in the evening, and after 6 p.m. it is catering primarily for people who have no television set. The vast majority of its day-time audiences, particularly in the early morning period and on Sundays, consists of people who have television sets. The inquiry showed that most people exercised their opportunity to choose between different programme services ; those who did so, both viewers and listeners, outnumbering single-service loyalists by about two to one; but those who settled for one service were by no means homogeneous in either choice or tastes. There was an abnormally high proportion of discriminating listeners among those who limit their listening to the Home Service, and an abnormally high proportion of discriminating viewers among those who, though they could view Independent television, rarely did so.

A relation was noted between the amount of time people devote to listening or viewing and the services they patronize. The more time a person spends in listening the greater the proportion of that time he is likely to give to the Light Programme; similarly, the more he views, the greater is likely to be the proportion of his time spent in viewing Independent television. The inquiry showed that the less a person listens or views the more likely he is to be selective, and the more selective he is, the more likely he is to prefer the kinds of programme characteristic of the Home Service and the B.B.C. television than of the Light Programme and Independent television. Again, the older a listener is, the less likely he is to enjoy feature films, crime series, or westerns. Sex is sometimes predictive, women being more likely than men to be 'heavy' consumers of both sound and television in the evening. Science features on television, ranging sixteenth out of eighteen categories in popularity with the public, were not unpopular with men but were unpopular with women and most unpopular with viewers over sixty. Their popularity increases with each step up the educational level, and most often the individual's behaviour, attitudes and tastes tend to be associated with the age when his full-time education ceased, and/or 'occupational status', frequently reinforced by information about the newspapers he reads. Again and again the report demonstrates that the higher the individual's cultural level, the less he tends to listen or view, the more likely he is to be selective and to take an interest in serious types of programmes. Whatever measure of 'cultural level' is used, the population appears as a sharply tapering pyramid, and, accordingly, the more a type of broadcasting output or service depends for its custom upon people who have enjoyed cultural advantages or want something more than the un. demanding relaxation, the more numerically restricted its audience is likely to be. So far as science is concerned the inquiry indicates that nearly all effective viewing is on B.B.C. television and hence anything that prejudices B.B.C. television as against Independent television would be liable to prejudice the use of television in the presentation of science to the public.

\section{AUTOMATION AND ITS HUMAN REPERCUSSIONS}

$\mathrm{T}$ HE mental health problems of automation were examined recently by a World Health Organization study group (Study Group on the Mental Health Problems of Automation. (World Health Organization Report, Series No. 183.) Pp. 30. Geneva : W.H.O. ; London : H.M. Stationery Office, 1959). It is not automation in the form of automatic co-ordination of machine tools on production lines, nor in the form of automatic control over manufacturing processes, that is liable to bring about the most revolutionary changes in mechanized work, but the rapid and automatic processing of an increasing range of technical and business information by the electronic digital computer.

Emotional reactions to automation range from unreasonable hopes of a rapid rise in living standards to fears of upheavals in conditions of employment and of difficulty in adaptation to the new machines. These reactions are of an anticipatory nature and are not based on actual experience. In the meantime, workers in automated undertakings are already suffering from physiologieal and psychological strain.

Because of its nature, automated work may have psychological consequences: for example, if the manual activity of a worker who has been accustomed to assess his work on the basis of his physical effort is reduced, he will feel himself less useful and suffer from a sense of inadequacy; if contact with the machine or with the object on which he is working is eliminated or reduced, he will see his task in a more abstract form and this may lead to anxiety; if his 